\title{
Analisis Hukum Penyelesaian Sengketa Pemilihan Kepala Desa di Kabupaten Kolaka
}

\section{Legal Analysis of the Dispute of Village Head Selection in Kolaka District}

\author{
Musdar \\ Kantor Kecamatan Tanggetada Kabupaten Kolaka \\ E-mail: audra.musdar84@gmail.com \\ Guasman Tatawu \\ Pascasarjana Universitas Halu Oleo \\ E-mail: gtatawu@gmail.com \\ Muh. Sabaruddin Sinapoy \\ Pascasarjana Universitas Halu Oleo \\ E-mail: sabaruddinsinapoy@yahoo.com
}

\begin{abstract}
The research objectives in this study were: 1) To analyze the dispute resolution of village head elections by the Kolaka Regency regional government. 2) To analyze the consequences of the law that arises for village heads who are appointed without first resolving disputes over village head elections. This research is empirical legal research research or field research which is based on primary or basic data, namely data obtained directly from the community as the main source through field research. The results of this study indicate that: First. Dispute Resolution of the Village Head Election by the Regional Government of Kolaka Regency. In Kolaka Regency, village head election dispute resolution was left entirely to the regent based on the prevailing laws and regulations, dispute resolution in village head elections as happened in the Kolaka district in 2016, 2017 and 2018 local government in this case the regent district head carried out a model deliberation settlement between the losing candidate and the winner. In 2016 and 2017 the settlement of the dispute did not cause problems for the parties, whereas in 2018 the settlement by deliberation by the regent was not accepted by one of the parties and opted for legal action. Second. Legal Consequences Occurred For Village Heads Inaugurated Without Priority Resolved Disputes on Village Head Election The consequences that arise if the winning village head candidate is still sworn in without a dispute resolution of 30 days of village head election in accordance with regional regulations, is a violation because election dispute resolution is mandatory implemented by the regent. However, if the outcome of the settlement has not been
\end{abstract}


agreed upon by one of the parties and the party that does not accept the choice to step in the general court (PTUN) will not stop the inauguration of the village head.

Keyword: Election of Village Heads; Kolaka District; Law Number 6 Year 2014 concerning Villages

\begin{abstract}
Abstrak: Tujuan penelitian dalam penelitian ini adalah: 1) Untuk menganalisis penyelesaian sengketa pemilihan kepala desa oleh pemerintah daerah Kabupaten Kolaka. 2) Untuk menganalisis konsekuensi hukum yang timbul bagi kepala desa yang dilantik tanpa terlebih dahulu diselesaikan sengketa pemilihan kepala desa. Hasil penelitian ini menunjukkan bahwa : Pertama. Penyelesaian Sengketa Pemilihan Kepala Desa Oleh Pemerintah Daerah Kabupaten Kolaka. Di Kabupaten Kolaka penyelesaian sengketa pemilihan kepala desa Sebagai diserahkan sepenuhnya kepada bupati berdasarkan peraturan perundang-undangan yang berlaku, penyelesaian sengketa dalam pemilihan kepala desa seperti yang terjadi di kabupaten Kolaka pada tahun 2016, 2017 dan 2018 pemerintah daerah dalam hal ini bupati kabupaten Kolaka melakukan model penyelesaian secara musyawarah antara calon yang kalah dan yang menang. Pada tahun 2016 dan 2017 penyelesaian sengketanya tidak menimbulkan permasalahan bagi pihak, sedangkan pada tahun 2018 penyelesaian secara musyawarah oleh bupati tidak diterima salah satu pihak dan memilih ke jalur hukum. Kedua. Konsekuensi Hukum Yang Timbul Bagi Kepala Desa Yang Dilantik Tanpa Terlebih Dahulu Diselesaikan Sengketa Pemilihan Kepala Desa Konsekuensi yang timbul apabila calon kepala desa yang menang tetap dilantik tanpa adanya penyelesaian sengketa pemilihan kepala desa selama 30 hari sesuai dengan peraturan daerah, merupakan pelanggaran karena penyelesaian sengketa pemilihan wajib dilaksanakan oleh bupati. Akan tetapi jika hasil penyelesaian belum disepakati oleh salah satu pihak dan pihak yang tidak terima memilih melangkah peradilan umum (PTUN) tidak akan menghentikan pelantikan kepala desa tersebut. Kata kunci: Pemilihan Kepala Desa; Kabupaten Kolaka; Undang-Undang Nomor 6 Tahun 2014 Tentang Desa
\end{abstract}

\title{
PENDAHULUAN
}

Berdasarkan Undang-Undang Dasar Negara Republik Indonesia Tahun 1945, Pasal 18 ayat (1) dan ayat (5) dinyatakan bahwa: (1) Negara Kesatuan Republik Indonesia di bagi atas daerah-daerah provinsi dan daerah provinsi itu dibagi atas kabupaten dan kota yang tiaptiap provinsi, kabupaten dan kota itu mempunyai pemerintahan daerah, yang diatur dengan undang-undang, dan pada ayat (5) menyebutkan bahwa: Pemerintahan daerah menjalankan otonomi seluas-luasnya, kecuali urusan pemerintahan yang oleh undangundang ditentukan sebagai urusan pemerintah pusat.

Menurut Miftah Thoha, dilaksanakannya otonomi daerah, karena mengingat luasnya wilayah Negara Indonesia dan demi efisiensi dalam kegiatan tugas Negara, dipandang tidak mungkin penyelenggaraan pemerintahan ditangani seluruhnya secara sentralistis oleh pemerintah pusat, ${ }^{1}$ di samping itu, pembatasan kekuasaan dan pembagian

1 Miftah Thoha, Birokrasi Pemerintah Indonesia Di Era Reformasi, Cetakan Ke II, Jakarta: Kencana Prenada Media Group, 2009. hlm. 37. 
kekuasaan pemerintahan juga dilakukan untuk menghindari terjadinya penumpukan atau sentralisasi kekuasaan pada suatu tangan atau lembaga, sebab sentralisasi kekuasaan akan mendorong kepada otoritarianisme dalam penyelenggaraan negara atau penyalahgunaan kekuasaan. ${ }^{2}$

Dalam tiap kabupaten atau kota tersebut terdapat satuan pemerintahan yang disebut desa dan kelurahan. Dasar pengaturan desa adalah Undang-Undang Dasar Negara Republik Indonesia Tahun 1945. UUD mengatur bahwa negara mengakui dan menghormati kesatuan-kesatuan masyarakat hukum adat beserta hak-hak tradisionalnya sepanjang masih hidup dan sesuai dengan perkembangan masyarakat dan prinsip Negara Kesatuan Republik Indonesia, serta mengamanatkan hal tersebut untuk diatur di dalam undang-undang. Saat ini, desa dan kelurahan adalah dua satuan pemerintahan paling bawah (bukan kedudukannya) dengan status yang berbeda. Desa adalah satuan pemerintahan yang diberi hak otonomi adat sehingga merupakan badan hukum sedangkan kelurahan adalah satuan pemerintahan administrasi yang hanya merupakan kepanjangan tangan dari pemerintah kabupaten/kota. ${ }^{3}$

Berkaitan dengan susunan dan penyelenggaraan Pemerintahan Daerah, setelah perubahan Undang-Undang Dasar Negara Republik Indonesia Tahun 1945, pengaturan Desa atau disebut dengan nama lain dari segi pemerintahannya mengacu pada ketentuan Pasal 18 ayat (7) yang menegaskan bahwa "Susunan dan tata cara penyelenggaraan Pemerintahan Daerah diatur dalam undang-undang". Hal itu berarti bahwa Pasal 18 ayat (7) Undang-Undang Dasar Negara Republik Indonesia Tahun 1945 membuka kemungkinan adanya susunan pemerintahan dalam sistem pemerintahan Indonesia. Melalui perubahan Undang-Undang Dasar Negara Republik Indonesia Tahun 1945, pengakuan terhadap kesatuan masyarakat hukum adat dipertegas melalui ketentuan dalam Pasal 18 B ayat (2) yang berbunyi "Negara mengakui dan menghormati kesatuankesatuan masyarakat hukum adat beserta hak-hak tradisionalnya sepanjang masih hidup dan sesuai dengan perkembangan masyarakat dan prinsip Negara Kesatuan Republik Indonesia, yang diatur dalam undang-undang". 4

Dengan adanya otonomi daerah ini maka daerah sendiri yang berhak mengatur dan menjalankan pemerintahannya sendiri tapi tetap berdasarkan aturan yang ada. Dalam

\footnotetext{
Adisasmita Rahardjo, Manajemen Pemerintahan Daerah, Yogyakarta: Graha Ilmu, 2011. hlm. 84.

3 Hanif Nurcholis, Pertumbuhan dan Penyelenggaraan Pemerintahan Desa, Jakarta: Erlangga, 2011, hlm. 72.

4 Penjelasan Atas Undang-Undang Republik Indonesia Nomor 6 Tahun 2014 Tentang Desa, pada angka romawi I, poin 1 bagian umum, dasar pemikiran.
} 
pengelolaan pemerintahan daerah yang bersifat otonom, segala proses penyelenggaraan di serahkan kepada daerah termasuk penyelenggaraan Pilkades yang selanjutnya diatur oleh Perda. Menurut Undang-undang Nomor 8 Tahun 2012 Terkait Pemilihan Umum, dalam Pasal 1 angka 1 disebutkan pemilihan umum, selanjutnya disebut pemilu adalah sarana pelaksanaan kedaulatan rakyat yang dilaksanakan secara langsung, umum, bebas, rahasia, jujur dan adil dalam Negara Kesatuan Republik Indonesia berdasarkan Pancasila dan Undang-Undang Dasar Negara Republik Indonesia Tahun 1945. Akan tetapi pada umumnya, istilah "pemilu" lebih sering merujuk kepada pemilihan anggota legislatif dan presiden yang diadakan setiap 5 tahun sekali. Keterlibatan seluruh masyarakat dalam pemilihan umum merupakan salah satu ciri dari pemerintahan yang demokratis. Termasuk Pengertian dari asas dekonsentrasi adalah suatu asas yang menyatakan pelimpahan wewenang dari Pemerintah Pusat atau kepala wilayah atau kepala instansi vertikal tingkat yang lebih tinggi kepada pejabat-pejabat daerah tetapi tanggung jawab tetap ada pada Pemerintah Pusat. ${ }^{5}$

Dalam penyelenggaraan pemilihan kepala desa yang selanjutnya disingkat Pilkades. Pilkades dalam penyelenggaraannya dipilih langsung oleh rakyat, bersifat langsung umum, bebas, rahasia, jujur dan adil dan tahapan penyelenggaraannya sama dengan Pilpres dan Pilkada kendati demikian Pilkades tidak dimasukkan dalam rezim pemilu yang diatur dalam Undang-undang Nomor 8 Tahun 2012 terkait Pemilu. Pilkades seakan menjadi anak tiri dalam pemilihan umum di Indonesia, padahal Pilkades pada proses penyelenggaraannya lebih rawan secara sosial, politik dibandingkan pemilupemilu yang lain. Pilkades selanjutnya di atur khusus dalam Undang-undang Nomor 6 Tahun 2014 Tentang Desa, yang sebelumnya diatur Undang-undang Nomor 32 Tahun 2004 Tentang Pemerintahan Daerah yang memuat pengaturan daerah sebagai daerah otonom dan mengakui pemerintahan desa sebagai sub sistem dari penyelenggaraan pemerintahan dan desa berhak, memiliki kewenangan untuk mengurus rumah tangga desa. ${ }^{6}$

Pemilihan kepala desa secara konseptual sangat erat terkait dengan upaya untuk mewujudkan tujuan yang hakiki dari adanya otonomi pemerintahan desa itu sendiri, yaitu terciptanya pemerintahan desa yang demokratis dan terwujudnya kesejahteraan

5 Hanif Nurcholis, Op.Cit., hlm. 72

6 Eko Sutoro, Kedudukan dan Kewenangan Desa, Forum Pengembangan Pembaharuan Desa, Yogyakarta: FPPD, 2014, hlm. 31. 
masyarakat desa. Adanya otonomi desa berarti adanya pengakuan hak untuk mengatur urusan rumah tanggahnya sendiri dengan dasar dari prakarsa dari masyarakat. Namun dalam pelaksanaannya namun hak, kewenangan dan kebebasan dalam penyelenggaraan otonomi desa harus tetap menjunjung nilai-nilai tanggung jawab terhadap Negara Kesatuan Republik Indonesia. ${ }^{7}$

Pemilihan kepala desa merupakan hal yang sangat penting dalam penyelenggaraan otonomi desa, karena di dalam penyelenggaraan otonomi di desa kepala desa mengemban fungsi yang penting dalam penyelenggaraan roda pemerintahan di tingkat desa. Dimana kita ketahui bahwa desa adalah kesatuan masyarakat hukum yang memiliki batas wilayah yang berwenang untuk mengatur dan mengurus urusan pemerintahan, kepentingan masyarakat setempat berdasarkan prakarsa masyarakat, hak asal-usul, dan atau hak tradisional yang diakui dan dihormati dalam sistem pemerintahan Negara Kesatuan Republik Indonesia. Undang-Undang Dasar Negara Republik Indonesia Tahun 1945 menegaskan bahwa Negara mengakui dan menghormati kesatuan masyarakat hukum adat beserta hak tradisionalnya sepanjang masih hidup dan sesuai dengan perkembangan masyarakat dan prinsip Negara Republik Indonesia. ${ }^{8}$

Pemerintah desa sendiri merupakan struktur yang paling bawah dalam sistem pemerintahan nasional, pemerintah desa mempunyai kedekatan dengan masyarakat dari berbagai lapisan, golongan, kepentingan dan berbagai persoalan dalam masyarakat. Hal ini menunjukkan bahwa jika pemerintahan desa berfungsi dengan baik, maka akan sangat memberikan pengaruh signifikan terhadap kemajuan di berbagai bidang dalam masyarakat. ${ }^{9}$

Di dalam Undang-Undang Nomor 6 Tahun 2014 tentang Desa telah terdapat pengaturan tentang kepala desa yang tertuang di Pasal 26 sampai dengan Pasal 47 yang pada intinya menjelaskan kewenangan, hak dan kewajiban, tata cara pemilihan, pemberhentian kepala desa. Begitu pula di dalam Peraturan Pemerintah Nomor 43 Tahun 2014 tentang Peraturan Pelaksanaan Undang-Undang Nomor 6 Tahun 2014 tentang Desa terdapat pengaturan tentang kepala desa yakni mulai Pasal 40 sampai dengan Pasal 60 yang intinya mengatur kewenangan, hak dan kewajiban, tata cara pemilihan, dan

\footnotetext{
Ibid., hlm. 32

Ibid., hlm. 34

Ibid., hlm. 37
} 
pemberhentian kepala desa; namun Peraturan Pemerintah Nomor 43 Tahun 2014 lebih bersifat teknis dan rinci karena merupakan peraturan pelaksana. ${ }^{10}$

Hadirnya peraturan perundang-undangan yang mengatur tentang desa, menghadirkan harapan yang besar bagi masyarakat awal berhasilnya roda pemerintahan dan pembangunan desa yang dimulai dari pemilihan kepala desa sampai jalannya roda pemerintahan desa. Pemilihan kepala desa merupakan wujud demokrasi di desa. Demokrasi secara umum berarti pemerintahan dari, oleh, dan untuk rakyat. Pemilihan kepala desa dikatakan merupakan wujud demokrasi di desa karena memastikan rakyat turut serta dalam pemerintahan berupa memilih pemimpinnya. ${ }^{11}$

Pada prosesnya pemilihan kepala desa terdapat pasal di dalam Undang-Undang Nomor 6 Tahun 2014 yang mengatur lembaga atau institusi mana yang berwenang menyelesaikan perselisihan hasil pemilihan Kepala Desa yakni Pasal 37 ayat (6) yang berbunyi:" dalam hal terjadi perselisihan hasil pemilihan Kepala Desa, Bupati/Walikota wajib menyelesaikan perselisihan dalam jangka waktu sebagaimana dimaksud dalam ayat (5)" Jangka waktu yang dimaksud dalam pasal tersebut adalah paling lama 30 (tiga puluh) hari sejak tanggal diterimanya penyampaian hasil pemilihan dari panitia pemilihan Kepala Desa. Namun Ketentuan tersebut tidak diatur secara rinci bagaimana mekanismenya. Tidak jelasnya pengaturan dan tidak tepatnya lembaga yang berwenang dalam penyelesaian perselisihan hasil pemilihan Kepala Desa sehingga menimbulkan berbagai permasalahan, seperti turut campurnya bupati dalam pemilihan kepala desa artinya keadaan ini tidak sesuai dengan asas otonomi asli yang dimiliki desa. ${ }^{12}$

Berdasarkan data awal penulis, pada kenyataannya terdapat, permasalahan mengenai pemilihan kepala desa dewasa ini tidak hanya terletak pada permasalahan hasil dari pemungutan suara tersebut, tetapi juga terjadi dalam hal kampanye maupun administrasi pencalonan kepala desa tersebut, hal itu dapat dilihat pada salah satu kabupaten di Provinsi Sulawesi tenggara, yakni di Kabupaten Kolaka berdasarkan data awal penulis, pelaksanaan pemilihan kepala desa di Kabupaten Kolaka yang berlangsung dalam kurun waktu tahun 2016, sampai dengan 2018 yang di ikuti oleh puluhan. desa, pada pelaksanaannya masih menimbulkan beberapa permasalahan, seperti adanya calon yang tidak mengikuti prosedur administrasi dalam pencalonan yaitu mengenai syarat

10 Ahmad Marjuki, “ Perkembangan Penyelesaian Sengketa Pilkades,” Al Qisthas: Jurnal Hukum Dan Politik, Vol. 6 No. 2, Juli-Desember 2015, hlm. 205.

11 Ibid., hlm. 207

12 Ibid., hlm. 207 
keterangan bebas narkoba di samping itu pada tahapan kampanye juga di temukan bahwa beberapa pasangan calon melanggar ketentuan dalam peraturan perundang-undangan yang mengatur tentang pemilihan kepala desa. ${ }^{13}$

Dari hasil observasi penulis, terdapat pelanggaran dalam pemilihan kepala desa dari lima Kecamatan yang menyelenggarakan pemilihan kepala desa serentak terdapat tiga kecamatan yang terindikasi terdapat pelanggaran dalam pemilihan kepala desa yakni Kecamatan Samaturu. Desa Lawulo terdapat warga yang memilih tidak terdaftar dalam DPT, Kecamatan Baula, Desa Watalara terdapat warga yang memilih tidak terdaftar dalam DPT, Kecamatan Tanggetada, Desa Petudua, terdapat beberapa warga yang memilih yang belum cukup umur dan warga yang bukan warga desa. Di samping itu terdapat calon kepala desa yang tidak melalui syarat serta prosedur administrasi yang ditetapkan oleh BPMD Kabupaten Kolaka seperti tidak adanya keterangan dokter namun tetap dimasukkan sebagai calon kepala desa. ${ }^{14}$ Sehubungan dengan permasalahan yang telah diuraikan, maka penulis tertarik untuk melakukan penelitian dengan judul: "Analisis Hukum Penyelesaian Sengketa Pemilihan Kepala Desa di Kabupaten Kolaka."

\section{ANALISIS DAN PEMBAHASAN}

\section{Penyelesaian Sengketa Pemilihan Kepala Desa Oleh Pemerintah Daerah Kabupaten}

\section{Kolaka}

Berdasarkan Undang-undang Desa yang berlaku saat ini, pemilihan kepala desa harus dilaksanakan secara serentak di seluruh wilayah Kabupaten. sesuai dengan amanat dari Undang-undang Nomor 6 Tahun 2014 Tentang Desa dan Peraturan Pemerintah Republik Indonesia Nomor 43 Tahun 2014 Tentang Peraturan Pelaksanaan Undang-Undang Nomor 6 Tahun 2014 Tentang Desa, selanjutnya pemerintah daerah Kabupaten Kolaka menerbitkan Peraturan Daerah Kabupaten Kolaka Nomor 4 Tahun 2015 Tentang Pemilihan Kepala Desa sebagai dasar pelaksanaan pemilihan desa di Kabupaten tersebut. Sebagaimana ditegaskan dalam Undang-undang desa Tahun 2014 Pasal 31 ayat (1) Pemilihan Kepala Desa dilaksanakan secara serentak di seluruh wilayah Kabupaten/Kota; dan ayat (2) Pemerintahan Daerah Kabupaten/Kota menetapkan kebijakan pelaksanaan

\footnotetext{
13 Observasi awal penulis pada beberapa di Kabupaten Kolaka pada saat pelaksanaan pemilihan desa pada saat pemilihan, Tanggal 24 Mei 2018. Pukul. 09.00-15.00. WITA.

14 Ibid.
} 
pemilihan Kepala Desa secara serentak sebagaimana dimaksud pada ayat (1) dengan Peraturan Daerah Kabupaten/Kota.

Berdasarkan Peraturan Daerah Kabupaten Kolaka Nomor 4 Tahun 2015 Tentang Pemilihan Kepala Desa pada BAB III Tahapan Pelaksanaan Pemilihan Bagian Kesatu Umum, Pasal 5 disebutkan bahwa Pemilihan Kepala Desa dilaksanakan melalui tahapan: a. persiapan; b. pencalonan; c. pemungutan dan penghitungan suara; d. penetapan hasil pemilihan; dan e. pelantikan. Sebagai aturan pelaksanaannya kemudian pemerintah daerah Kabupaten Kolaka menerbitkan Peraturan Bupati Kolaka Nomor 43 Tahun 2015 Tentang Pelaksanaan Peraturan Daerah Kabupaten Kolaka Nomor 4 Tahun 2015 Tentang Pemilihan Kepala Desa.

Pada pelaksanaannya pemilihan desa di Kabupaten Kolaka, walaupun telah memiliki dasar hukum dalam proses pemilihan yang mengatur sejak dari tahapan persiapan sampai pelantikan pada kenyataannya masih menimbulkan sengketa antara calon yang terpilih dan tidak terpilih, baik itu mengenai syarat administrasi sampai dengan jumlah pemilih pada saat pemilihan kepala desa berlangsung, dari tiga tahun pemilihan kepala desa yang di kabupaten Kolaka, tiga tahun terakhir yakni pemilihan desa di tahun 2016, 2017 dan tahun 2018 ditemui beberapa permasalahan.

Berdasarkan data yang peneliti dapatkan di lapangan pemilihan kepala desa di Kabupaten Kolaka pada tahun 2016 yang diikuti sepuluh kecamatan dan lima puluh empat desa masih terdapat pelanggaran dalam proses pemungutan suara sebagaimana dapat dilihat pada tabel ke 1 di atas, pada pelaksanaannya pemilihan kepala desa di Desa Toari Kecamatan Toari masih di temukan warga yang ikut memilih sementara dari segi umur belum layak untuk memilih. artinya warga tersebut telah melanggar ketentuan. ${ }^{15}$

Berdasarkan hasil wawancara peneliti dengan Akbar, S.Sos. MM. Kepala BPMD Kabupaten Kolaka mengatakan bahwa:

Pada saat pemilihan kepala desa di tahun 2016 dari 54 desa yang mengikuti pemilihan terdapat satu desa mempermasalahkan mengenai hasil pemilihan tersebut, akan tetapi pada saat itu kami telah memberikan rekomendasi kepada Bupati untuk diselesaikan sesuai dengan perda kabupaten Kolaka, dan hasilnya pada saat itu, pihak yang kalah sudah maupun yang menang telah terima dengan hasil keputusan bupati tentang

15 Hasil penelitian peneliti, pada tanggal 18-1-2019. 
penyelesaian permasalahan hasil pemungutan suara yang di permasalahan antara yang menang dan yang kalah. ${ }^{16}$

Pendapat yang sama juga di katakan oleh salah satu panitia pemilihan di kepala desa tahun 2016 di Desa Toari. Berdasarkan hasil wawancara peneliti dengan Ansar (panitia pemilihan kepala desa mengatakan bahwa:

Sewaktu pemilihan kepala desa di desa Toari saya sebagai panitia pemilihan kepala desa menyaksikan pada saat itu terjadi permasalahan mengenai pemilihan kepala desa antara calon kepala desa yang ikut dalam pemilihan tersebut, permasalahannya yaitu ditemukan adanya warga yang memilih tetapi belum cukup umur, akan tetapi orang tersebut sudah pernah menikah, oleh sebabnya kami perbolehkan untuk melakukan pencoblosan, permasalahan pada saat itu langsung diselesaikan oleh bupati berdasarkan rekomendasi BPMD Kabupaten Kolaka. ${ }^{17}$

Sementara itu pada pemilihan kepala desa di Kabupaten Kolaka yang berlangsung pada tahun 2017 berdasarkan data yang peneliti dapatkan, pemilihan desa pada saat itu di ikuti oleh delapan kecamatan dua puluh empat desa, pada pelaksanaannya juga masih menimbulkan permasalahan. Berdasarkan data yang penulis dapatkan pemilihan kepala desa waktu itu di ikuti delapan kecamatan dan dua puluh empat desa. Dari beberapa desa yang mengikuti pemilihan kepala desa terdapat dua desa yang bermasalah mengenai hasil penghitungan suara yaitu Desa Watalara Kecamatan Baula ditemukan warga yang memilih tetapi tidak terdaftar dalam DPT, selain itu di Desa Petudua Kecamatan Tanggetada ditemukan ada warga yang ikut memilih tetapi sebenarnya belum bisa memilih karna aturan. ${ }^{18}$

Menurut Muksin. S.Sos., Kepala Seksi Humas BPMD Kabupaten Kolaka mengatakan bahwa pemilihan kepala desa pada tahun 2017 yang diikuti delapan kecamatan tidak berjalan dengan baik karena dari dua puluh empat desa yang mengikuti pemilihan terdapat dua desa yang bermasalah dalam pemilihan tersebut berlangsung, dua desa tersebut yakni desa Watalara dan Petudua saat itu sengketa yang timbul dalam pemilihan kepala desa tersebut penyelesaiannya kami serahkan kepada bupati langsung, dari hasil penyelesaian sengketa oleh bupati pada saat itu intinya hasil pemilihan kepala desa di dua

\footnotetext{
16 Wawancara peneliti, dengan Akbar, S.Sos. MM. (Kepala BPMD Kabupaten Kolaka) pada tanggal 19-12019. Jam. 09.20. WITA.

17 Wawancara peneliti, Ansar (Panitia Pemilihan Kepala Desa Toari Tahun 2016) pada tanggal 19-1-2019. Jam. 10.30. WITA.

18 Hasil penelitian peneliti, pada tanggal 18-1-2019.
} 
desa yang bermasalah tersebut, tidak di lakukan pemilihan ulang dan bupati tetap melakukan pelantikan. ${ }^{19}$

Menurut Israwan calon kepala Desa Watalara yang tidak terpilih pada saat pemilihan desa 2017 mengatakan bahwa tahun 2017 beliau mengikuti pemilihan kepala desa sebagai calon kepala desa nomor urut dua, pada saat itu suara beliau kalah banyak dari nomor urut satu yaitu selisih 11 suara akan tetapi pada saat pemilihan ada dua orang warga yang tidak terdaftar di dalam DPT ikut memilih, hal itulah yang pertanyakan kepada panitia pemilihan waktu itu, namun panitia tidak menjelaskan dengan baik sehingga pada saat itu permasalahan pemilihan kepala desa di desa Watalara di rekomendasikan oleh pihak BPMD untuk langsung diselesaikan oleh bupati hasil dari penyelesaian pada saat itu, tetap memenangkan pihak nomor urut satu. ${ }^{20}$

Pada tahun 2018, berdasarkan data yang didapatkan sebagaimana dapat dilihat pada tabel 3 di atas, pemilihan kepala desa di Kabupaten Kolaka diikuti 8 kecamatan dan dua puluh 20 pada kenyataannya juga masih terdapat permasalahan seperti pada saat pemilihan desa di tahun sebelumnya, karena dari delapan kecamatan dan dua puluh dua desa yang mengikuti pemilihan desa pada tahun tersebut ditemukan permasalahan dalam pemilihan kepala desa yaitu di Desa Popalia Kecamatan Tanggetada dalam pemilihan kepala desa terdapat penggelembungan suara dalam hal ini terdapat selisih antara warga yang memilih, dengan penggelembungan suara kemudian menjadi sengketa yang penyelesaiannya diserahkan kepada pihak pemerintah daerah dalam hal ini bupati sesuai dengan peraturan daerah kabupaten Kolaka mengenai pemilihan kepala desa. ${ }^{21}$

Berdasarkan hasil penelitian peneliti, dalam pemilihan kepala desa tersebut di ikuti oleh empat calon kepala desa adapun hasil dari pemilihan desa pada saat itu yaitu:

Tabel 1: Desa Tempat Terjadinya Sengketa Pemilihan Kepala Desa 2018

\begin{tabular}{ccccc}
\hline No. & $\begin{array}{c}\text { Nama Calon Kepala Desa } \\
\text { Popalia }\end{array}$ & Nomor Urut & Jumlah Suara & Keterangan \\
\hline 1 & Yusran, S.Pd & I & 370 & Terima \\
\hline 2 & Darmin & II & 356 & Tidak Terima \\
\hline 3 & H. Yudu & III & 52 & Tidak Terima \\
\hline 4 & Nasrin & IV & 22 & Tidak Terima \\
\hline \multicolumn{4}{c}{ Sumber data: BPMD Kabupaten Kolaka }
\end{tabular}

\footnotetext{
19 Wawancara peneliti dengan Muksin. S.Sos. Kepala Seksi Humas BPMD Kabupaten Kolaka pada tanggal 22-1-2019. Jam. 10.30. WITA.

20 Wawancara peneliti dengan Israwan calon kepala Desa Watalara tidak terpilih pada tahun 2017 pada tanggal 22-1-2019. Jam. 10.30. WITA.

21 Hasil penelitian peneliti, pada tanggal 18-1-2019.
} 
Dari tabel di atas, terlihat bahwa pemilihan desa pada tahun 2018 yang di ikuti delapan kecamatan menimbulkan sengketa pilkades pada salah satu desa yakni Desa Popalia, karena tiga calon tidak menerima hasil penghitungan suara yang dilakukan oleh panitia pemilihan desa, dan kemudian melakukan penolakan hasil pemungutan suara sampai kepada bupati.

Menurut penulis, berdasarkan hasil penelitian peneliti baik itu yang terdapat pada tabel di atas, maupun hasil wawancara peneliti serta observasi peneliti, pada pelaksanaannya pemilihan desa ditahun tersebut masih ditemukan bahwa dari tiga tahun pemilihan kepala desa serentak yang di laksanakan di Kabupaten Kolaka oleh pemerintah daerah mengikuti pemilihan desa masih terdapat sengketa pada saat pemilihan desa tersebut berlangsung, karena dari beberapa kecamatan yang ikut pemilihan kepala desa serentak pada saat itu ditemukan beberapa warga masyarakat desa yang ikut memilih tetapi tidak terdaftar dalam DPT di masing-masing desa, di samping itu dalam pemilihan tersebut juga ditemukan beberapa warga masyarakat yang ikut memilih tetapi sebenarnya belum bisa memilih karna aturan (belum mencapai satu tahun tinggal di desa tersebut), hal inilah yang kemudian menjadi sengketa bagi beberapa calon kepala desa yang tidak terpilih yang ikut dalam pemilihan desa serentak di Kabupaten Kolaka.

Jika melihat hasil penelitian di atas, penyelesaian sengketa dalam pemilihan kepala desa serentak yang terjadi di Kabupaten Kolaka, penyelesaiannya, sepenuhnya menjadi tanggung jawab pihak pemerintah daerah dalam hal ini Bupati Kolaka hal ini sesuai dengan apa yang disebutkan dalam undang-undang tentang desa serta Peraturan Daerah Kabupaten Kolaka Nomor Tahun 2015 Tentang Pemilihan Kepala Desa. Walaupun pada sisi lain masih ada calon kepala desa yang tidak terpilih belum menerima hasil penyelesaian yang dilakukan oleh Bupati Kolaka pada saat itu.

Menurut penulis, tanggung jawab bupati dalam penyelesaiannya sengketa pemilihan desa sebagaimana disebutkan dalam Undang-Undang Nomor 6 Tahun 2014 tentang Desa, dalam undang-undang tersebut mengatur beberapa tahapan pemilihan termasuk mengenai pemilihan kepala desa serta mekanisme penyelesaian perselisihan hasil pemilihan Kepala Desa yang diatur di dalam Pasal 37 ayat (6) Undang-Undang Nomor 6 Tahun 2014 tentang Desa yang menyebutkan bahwa: "Dalam hal terjadi perselisihan hasil pemilihan Kepala Desa, Bupati/Walikota wajib menyelesaikan perselisihan dalam jangka waktu sebagaimana dimaksud pada ayat (5)"Jangka waktu penyelesaian perselisihan hasil pemilihan Kepala Desa ini adalah 30 hari sejak tanggal diterimanya 
penyampaian hasil pemilihan dari panitia pemilihan Kepala Desa. Hal ini diatur di dalam Pasal 37 ayat (5) Undang-Undang Nomor 6 Tahun 2014 yakni: (5) Bupati/Walikota mengesahkan calon Kepala Desa terpilih sebagaimana dimaksud pada ayat (3) menjadi Kepala Desa paling lama 30 (tiga puluh) hari sejak tanggal diterimanya penyampaian hasil pemilihan dari panitia pemilihan Kepala Desa dalam bentuk keputusan Bupati/Walikota.

Selanjutnya penyelesaian sengketa hasil pemilihan kepala desa kemudian dilakukan pemerintah daerah dalam hal ini bupati Kolaka karena kembali di pertegas dalam Peraturan Daerah Kabupaten Kolaka Nomor Tahun 2015 Tentang Pemilihan Kepala Desa, Bagian Keempat penetapan Hasil Pemilihan, Pasal 46 yang menyebutkan bahwa:

(1) Dalam hal terjadi perselisihan hasil pemilihan kepala Desa, Bupati wajib menyelesaikan perselisihan dalam jangka waktu 30 (tiga puluh) Hari.

(2) Apabila setelah penyelesaian perselisihan dalam jangka waktu sebagaimana dimaksud pada ayat (1) masih terdapat pengajuan keberatan atas penetapan calon Kepala Desa terpilih, maka pelantikan calon Kepala Desa terpilih tetap dilaksanakan

(3) Tata cara penyelesaian perselisihan sebagaimana dimaksud pada ayat (1) diatur lebih lanjut dalam Peraturan Bupati.

Penulis melihat, penyelesaian sengketa dalam pemilihan kepala desa seperti yang terjadi di kabupaten Kolaka pada tahun 2016 dan 2017 cara penyelesaiannya sengketa pemilihan desa yang ditempuh oleh pemerintah daerah dalam hal ini bupati kabupaten Kolaka tidak menimbulkan permasalahan bagi pihak yang dirugikan dari karena dalam terselesaikan oleh bupati Kolaka dalam kurun waktu 30 hari, tanpa adanya upaya hukum lebih lanjut dengan adanya surat penetapan pelantikan kepala desa terpilih, calon kepala desa yang kalah dalam pemilihan kepala desa yang dikuti beberapa desa pada tahun 2017 hanya mengajukan keberatan pada pemerintah daerah namun hasil penyelesaian sengketa pada saat itu tidak dapat menghentikan pelantikan kepala desa terpilih.

Sementara itu, penyelesaian sengketa pemilihan kepala desa pada tahun 2018 di Kabupaten Kolaka telah dilakukan penyelesaian sengketanya sama seperti pada penyelesaian sengketa pada tahun sebelumnya yakni menggunakan metode penyelesaian sengketa melalui pemerintah daerah dalam hal ini oleh bupati akan tetapi tiga orang calon kepala desa di Desa Popalia yang tidak terpilih yakni: Darmin, H. Yudu. dan Nasrin tidak menerima hasil penyelesaian sengketa yang diselesaikan oleh bupati sehingga masih mengajukan keberatan dengan cara mengajukan gugatan ke lembaga peradilan yaitu 
Pengadilan Tata Usaha Negara di Kendari perihal surat keputusan yang di keluarkan bupati Kolaka tentang pelantikan kepala desa terpilih pada pemilihan serentak $2018 .^{22}$

Menurut peneliti, berdasarkan ketentuan perundang-undangan maka penyelesaian sengketa hasil Pemilihan Kepala Desa menjadi kewajiban Bupati Kolaka seperti persilihan/sengketa mengenai pemilihan desa serentak di Kabupaten Kolaka di dalam penyelesaian perselisihan hasil pemilihan kepala desa, para pihak terpaksa harus menyelesaikan sengketa kepada bupati karena telah diatur di dalam undang-undang. Sementara itu, menurut hasil analisa peneliti, pada sisi lain independensi bupati dalam penyelesaian sengketa pemilihan kepala desa patut dipertanyakan karena masih memiliki relevansi dengan partai politik, selain itu, para pihak belum tentu sepakat untuk menyelesaikan sengketa di muka bupati, sebab walaupun pihak yang kalah dalam pemilihan kepala desa bisa membuktikan adanya pelanggaran dalam pemilihan kepala desa baik itu dari tahapan pertama sampai dengan tahapan terakhir penghitungan suara pada kenyataannya tidak direspons dengan baik oleh bupati sehingga pelantikan calon kepala desa terpilih tetap dilaksanakan.

Peneliti melihat, Undang-Undang Nomor 6 Tahun 2014 Tentang Desa, sudah dijelaskan bahwa apabila ada perselisihan pemilihan kepala desa (Pilkades), Bupati yang diberikannya wewenang untuk menyelesaikan perselisihan Pemilihan Kepala Desa (Pilkades), diberikannya wewenang Bupati/Walikota untuk menyelesaikan perselisihan Pemilihan Kepala Desa, menurut, peneliti kurang efektif karena Bupati adalah jabatan politik yang setiap Pemilihan Umum Kepala Daerah membutuhkan suara untuk maju kembali menjadi Bupati sehingga penyelesaian sengketa pemilihan kepala desa bisa mengganggu demokrasi dalam sistem otonomi desa di Indonesia.

Menurut peneliti, penyelesaian sengketa pemilihan kepala desa berdasarkan peraturan daerah menjadi tanggung jawab pemerintah daerah dalam hal ini bupati seperti yang terjadi di Kabupaten Kolaka, akan tetapi dalam penyelesaiannya menurut peneliti, tidak menggambarkan asas penyelenggaraan pemerintahan desa yang disebutkan Undang-Undang Republik Indonesia Nomor 6 Tahun 2014 Tentang Desa, Pasal 3 Pengaturan Desa berasaskan huruf (i). kemandirian; karena pemerintahan desa tidak di berikan kemandirian untuk melakukan penyelesaian sengketa pemilihan kepala desa

22 Hasil observasi peneliti di lapangan pada tanggal 27-1-2019. 
sendiri dikarenakan penyelesaian sengketa pemilihan kepala desa hanya menjadi kewenangan bupati.

Menurut hasil analisa peneliti, bahwa sebagai penyelenggara pemerintahan yang dapat diusung oleh partai politik, peran bupati dalam penyelesaian perselisihan hasil pemilihan kepala desa dikhawatirkan akan menimbulkan kepentingan yakni calon yang dimenangkan adalah calon yang memiliki koneksi dengan bupati dengan harapan politik balas budi. Kekuasaan koneksi adalah kekuasaan yang timbul karena hubungan yang dijalin dengan orang-orang yang berpengaruh, baik di luar maupun di dalam sebuah pemerintahan. Akibat diselesaikan oleh bupati, dalam kasus seperti yang telah disebutkan pada hasil penelitian di atas, bupati menerbitkan Surat Keputusan tentang Pengesahan Calon Kepala Desa Terpilih. Hal ini dilakukan meskipun perselisihan hasil pemilihan kepala desa tidak diterima oleh salah satu pihak yang kalah di samping itu, jika melihat apa yang terjadi di Kabupaten Kolaka walaupun pihak yang kalah tersebut bisa membuktikan adanya kecurangan dalam pemilihan kepala desa akan tetapi pelantikan tetap dilaksanakan.

Seharusnya penyelesaian perselisihan Pemilihan Kepala Desa (Pilkades) diselesaikan oleh lembaga yudikatif, dan pemerintah dapat merevisi Undang-Undang Desa terutama pada Pasal 37 ayat 6 dengan memasukkan salah satu unsur pasal yang menyebutkan untuk penyelesaian perselisihan Pemilihan Kepala Desa (Pilkades) diberikan kewenangan kepada lembaga yudikatif yang sebelumnya sepenuhnya menjadi tanggung jawab Bupati, atau dibuatkan Peradilan Khusus sebagai lembaga di luar Yudikatif, asalkan pembentuk Undang-Undang menetapkan hal tersebut, di beberapa negara peradilan khusus itu bisa dilakukan oleh lembaga di luar Mahkamah Agung (MA) maupun Mahkamah Konstitusi (MK), oleh sebab itu kita bisa dilakukan menyerahkan peradilan itu kepala sebuah lembaga seperti Bawaslu asalkan diberikan wewenang yang tegas oleh Undang-Undang sehingga penyelesaian perselisihan Pemilihan Kepala Desa diselesaikan di luar eksekutif, menurut Peneliti Penyelesaian perselisihan Pemilihan Kepala Desa (Pilkades) di luar eksekutif lebih efektif karena tidak adanya kepentingan politik atau intervensi dalam penyelesaian Perselisihan Pemilihan Kepala Desa. 


\section{Konsekuensi Hukum Yang Timbul Bagi Kepala Desa Yang Dilantik Tanpa Terlebih Dahulu Diselesaikan Sengketa Pemilihan Kepala Desa}

Pemilihan Kepala Desa secara serentak yang dilaksanakan pemerintah daerah Kabupaten Kolaka sesuai amanat yang terkandung dalam Undang-undang Nomor 6 Tahun 2014 Tentang Desa, maka selanjutnya dituangkanlah dalam bentuk perda yang menjadi landasan hukum pelaksanaan Pemilihan Kepala Desa Secara Serentak di Kabupaten Kolaka yakni, Peraturan Daerah Kabupaten Kolaka Nomor 4 Tahun 2015 Tentang Pemilihan Kepala Desa, sebagai peraturan pelaksanaan dari perda tersebut maka diatur lagi dalam bentuk Peraturan Bupati yakni Peraturan Bupati Kolaka Nomor 43 Tahun 2015 Tentang Peraturan Pelaksanaan Peraturan Daerah Kabupaten Kolaka Nomor 4 Tahun 2015 Tentang Pemilihan Kepala Desa.

Berdasarkan Undang-Undang Nomor 6 Tahun 2014 Tentang Desa kewenangan untuk melakukan pelantikan yakni berada ditangan bupati Hal ini disebabkan dalam Pasal 37 undang-undang desa tersebut telah disebutkan bahwa:

(1) Calon Kepala Desa yang dinyatakan terpilih adalah calon yang memperoleh suara terbanyak.

(2) Panitia pemilihan Kepala Desa menetapkan calon Kepala Desa terpilih.

(3) Panitia pemilihan Kepala Desa menyampaikan nama calon Kepala Desa terpilih kepada Badan Permusyawaratan Desa paling lama 7 (tujuh) hari setelah penetapan calon Kepala Desa terpilih sebagaimana dimaksud pada ayat (2).

(4) Badan Permusyawaratan Desa paling lama 7 (tujuh) hari setelah menerima laporan panitia pemilihan menyampaikan nama calon Kepala Desa terpilih kepada Bupati/Walikota.

(5) Bupati/Walikota mengesahkan calon Kepala Desa terpilih sebagaimana dimaksud pada ayat (3) menjadi Kepala Desa paling lama 30 (tiga puluh) hari sejak tanggal diterimanya penyampaian hasil pemilihan dari Panitia pemilihan Kepala Desa dalam bentuk keputusan Bupati/ Walikota.

(6) Dalam hal terjadi perselisihan hasil pemilihan Kepala Desa, Bupati/ Walikota wajib menyelesaikan perselisihan dalam jangka waktu sebagaimana dimaksud pada ayat (5).

Selanjutnya kewenangan bupati untuk melakukan pelantikan disebutkan dalam Pasal 38 Ayat (1) disebutkan: Calon Kepala Desa terpilih dilantik oleh Bupati/Walikota atau pejabat yang ditunjuk paling lama 30 (tiga puluh) hari setelah penerbitan keputusan 
Bupati/Walikota. Hal yang sama juga disebutkan dalam Pasal 45 Peraturan Daerah Kabupaten Kolaka Nomor Tahun 2015 Tentang Pemilihan Kepala Desa, disebutkan bahwa:

(1) PPKD menyampaikan laporan hasil pemilihan Kepala Desa kepada BPD paling lambat 7 (tujuh) Hari setelah pemungutan suara.

(2) BPD menyampaikan laporan hasil pemilihan kepala Desa sebagaimana dimaksud pada ayat (1) kepada Bupati melalui Camat dengan tembusan kepada Kepala Desa paling lambat 7 (tujuh) Hari setelah menerima laporan PPKD.

(3) Bupati menetapkan pengesahan dan pengangkatan Kepala Desa terpilih dengan keputusan Bupati paling lambat 30 (tiga puluh) Hari sejak diterima laporan dari BPD.

(4) Apabila Calon Kepala Desa terpilih meninggal dunia sebelum dilantik, maka akan diadakan pemilihan ulang sesuai peraturan perundang-undangan.

Berdasarkan peraturan yang berlaku mengenai pemilihan kepala desa seperti yang telah disebutkan di atas, jika kita melihat pemilihan Kepala Desa di Kabupaten Kolaka yang dilaksanakan serentak yaitu pada tahun 2016, 2017, dan 2018 masih menyisakan permasalahan pada pelaksanaannya sebab tidak selalu sejalan dengan apa yang diharapkan karena beberapa desa yang mengikuti pemilihan serentak di kabupaten Kolaka masih saja terdapat penggelembungan suara sehingga timbul sengketa dalam pemilihan tersebut. Pihak pemerintah daerah dalam hal ini Bupati Kolaka sesuai dengan kewenangannya telah menyelesaikan sengketa dalam pemilihan tersebut, dalam kurung waktu 30 hari sejak diterimanya laporan dari BPD. Sesuai dengan apa yang disebutkan dalam peraturan daerah. kemudian setelah diselesaikan secara musyawarah kemudian barulah pelantikan kepala desa terpilih dilaksanakan sekalipun masih ada pihak yang merasa keberatan. ${ }^{23}$

Berdasarkan hasil wawancara peneliti dengan Akbar, S.Sos. MM. Kepala BPMD Kabupaten Kolaka mengatakan bahwa pemerintah daerah kabupaten Kolaka dalam hal ini Bupati Kolaka dengan adanya sengketa yang timbul di setiap pemilihan kepala desa, selalu melakukan penyelesaian permasalahan hasil pemungutan suara terlebih dahulu, dan kemudian melakukan pelantikan, sekalipun masih ada salah satu pihak yang masih keberatan. Hal itu dilakukan karena merupakan ketentuan yang disebutkan dalam perda kabupaten Kolaka. Lebih lanjut dijelaskan, apabila tidak diselesaikan terlebih dahulu

23 Hasil observasi peneliti di lapangan pada tanggal 27-1-2019. 
sengketa pemilihan kepala desa maka secara tidak langsung terjadi pelanggaran terhadap perda tersebut. ${ }^{24}$

Menurut penulis berdasarkan apa yang di jelaskan dalam hasil wawancara di atas, pada dasarnya, konsekuensi hukum yang timbul bagi kepala desa yang dilantik tanpa terlebih dahulu diselesaikan sengketa pemilihan kepala desa merupakan sebuah pelanggaran terhadap salah satu tahapan dari beberapa rangkaian tahapan dalam pemilihan kepala desa yang disebutkan dalam perda kabupaten Kolaka tentang pemilihan kepala desa. Akan tetapi dalam penyelesaian tersebut, sekalipun salah satu pihak masih merasa keberatan, pelantikan tetap dilaksanakan.

Menurut penulis berdasarkan hasil penelitian di atas, terlihat bahwa kepala desa yang dilantik tanpa terlebih dahulu diselesaikan sengketa pemilihan kepala desa oleh bupati, merupakan sebuah pelanggaran peraturan yang dapat saja membatalkan hasil pemilihan kepala desa pada saat itu, karena ada kewajiban yang diberikan oleh undangundang akan adanya penyelesaian sengketa terlebih dahulu kemudian barulah pelantikan di dapat dilaksanakan akan tetapi apabila salah satu pihak masih merasa keberatan dengan adanya penyelesaian oleh pihak pemerintah daerah dalam hal ini bupati kabupaten Kolaka seperti pada pemilihan desa di Kecamatan Toari Desa Popalia pada tahun 2018 maka tidak akan menimbulkan konsekuensi hukum apa pun karena pelantikan akan tetap dilaksanakan, hal itu sebagaimana disebutkan Peraturan Daerah Kabupaten Kolaka Nomor Tahun 2015 Tentang Pemilihan Kepala Desa, Bagian Keempat penetapan Hasil Pemilihan Pasal 46 yang menyebutkan bahwa:

1. Dalam hal terjadi perselisihan hasil pemilihan kepala Desa, Bupati wajib menyelesaikan perselisihan dalam jangka waktu 30 (tiga puluh) Hari.

2. Apabila setelah penyelesaian perselisihan dalam jangka waktu sebagaimana dimaksud pada ayat (1) masih terdapat pengajuan keberatan atas penetapan calon Kepala Desa terpilih, maka pelantikan calon Kepala Desa terpilih tetap dilaksanakan

3. Tata cara penyelesaian perselisihan sebagaimana dimaksud pada ayat (1) diatur lebih lanjut dalam Peraturan Bupati.

Penulis melihat sekalipun hasil pemungutan suara pada tahun 2018 di Kecamatan Toari Desa Popalia, tidak diterima oleh calon kepala desa yang kalah yakni, Darmin. H.

24 Wawancara peneliti, dengan Akbar, S.Sos. MM. (Kepala BPMD Kabupaten Kolaka) pada tanggal 19-12019. Jam. 09.20. WITA. 
Yudu. Nasrin, dan berujung adanya gugatan ke peradilan PTUN, akan tetapi pelantikan tetap wajib untuk di laksanakan bupati tanpa harus menunggu hasil keputusan peradilan PTUN tersebut, karena belum ada satu pasal pun di dalam peraturan perundang-undangan yang mengatur mengenai pemilihan desa menyebutkan bahwa Sengketa Pemilihan Kepala Desa diselesaikan di ranah peradilan umum, akan tetapi sengketa pemilihan kepala desa hanya diselesaikan oleh pihak pemerintah daerah dalam hal ini bupati kabupaten Kolaka sesuai dengan peraturan perundang-undangan yang berlaku. 25

Menurut penulis, tidak adanya konsekuensi hukum yang timbul bagi kepala desa yang dilantik tanpa terlebih dahulu diselesaikan sengketa pemilihan kepala desa merupakan pelanggaran namun jika hasil penyelesaian oleh bupati tidak diterima oleh satu pihak dan melangkah peradilan umum (PTUN) tidak akan berdampak apa-apa atau dengan kata lain tidak akan mempengaruhi pelantikan karena dalam undang-undang desa mengonstruksi Pilkades sebagai rezim Pemerintah Daerah, sehingga wajar jika peran Pemerintah Kabupaten begitu kuat. Kuatnya rezim pemerintah daerah dalam proses Pilkades tercermin dalam beberapa pasal yang mengatur tentang pemilihan kepala desa, terutama pada pasal 37 ayat (6) undang-undang tentang desa yang menyatakan bahwa proses penyelesaian sengketa Pemilihan Kepala Desa diselesaikan oleh Bupati/Walikota.

Merujuk pada ketentuan ini pula maka proses pengawasan terhadap Pilkades juga menjadi ranah Pemerintah Kabupaten/Kota. Pada praktiknya, panitia pengawas Pilkades dibentuk oleh kecamatan, sehingga segala hal yang terkait dengan pengaduan pelanggaran akan ditampung oleh tim ini sebagai representasi dari Pemerintah Kabupaten. Mengacu pada temuan tim inilah kemudian Bupati menyelesaikan terjadinya proses sengketa Pilkades.

\section{KESIMPULAN}

Berdasarkan uraian-uraian yang telah dijelaskan maka penulis dapat menyimpulkan bahwa:

1. Penyelesaian Sengketa Pemilihan Kepala Desa Oleh Pemerintah Daerah Kabupaten Kolaka. Di Kabupaten Kolaka penyelesaian sengketa pemilihan kepala desa Sebagai diserahkan sepenuhnya kepada bupati berdasarkan peraturan perundang-undangan yang berlaku, seperti Peraturan Daerah

25 Pengamatan penulis di lapangan pada tanggal 19-1-2019. 
Kabupaten Kolaka Nomor Tahun 2015 Tentang Pemilihan Kepala Desa berdasarkan perda tersebut. penyelesaian sengketa dalam pemilihan kepala desa seperti yang terjadi di kabupaten Kolaka pada tahun 2016, 2017 dan 2018 pemerintah daerah dalam hal ini bupati kabupaten Kolaka melakukan model penyelesaian secara musyawarah antara calon yang kalah dan yang menang. Pada tahun 2016 dan 2017 penyelesaian sengketanya tidak menimbulkan permasalahan bagi pihak, sedangkan pada tahun 2018 penyelesaian secara musyawarah oleh bupati tidak diterima salah satu pihak dan memilih ke jalur hukum.

2. Konsekuensi Hukum Yang Timbul Bagi Kepala Desa Yang Dilantik Tanpa Terlebih Dahulu Diselesaikan Sengketa Pemilihan Kepala Desa. Konsekuensi yang timbul apabila calon kepala desa yang menang tetap dilantik tanpa adanya penyelesaian sengketa pemilihan kepala desa selama 30 hari sesuai dengan peraturan daerah, merupakan sebuah pelanggaran karena penyelesaian sengketa pemilihan wajib dilaksanakan oleh bupati. Akan tetapi jika hasil penyelesaian belum disepakati oleh salah satu pihak dan pihak yang tidak terima memilih melangkah peradilan umum (PTUN) tidak akan menghentikan pelantikan kepala desa tersebut. Artinya, para pihak yang bersengketa terima atau tidak hasil penyelesaian sengketa pemilihan kepala desa oleh bupati tidak akan dapat menghentikan pelantikan.

\section{Daftar Pustaka}

Marjuki, Ahmad, “Perkembangan Penyelesaian Sengketa Pilkades,” Al Qisthas: Jurnal Hukum Dan Politik, Vol. 6 No. 2, Juli-Desember 2015.

Nurcholis, Hanif, Pertumbuhan dan Penyelenggaraan Pemerintahan Desa, Jakarta: Erlangga, 2011.

Rahardjo, Adisasmita, Manajemen Pemerintahan Daerah, Yogyakarta: Graha Ilmu, 2011.

Sutoro, Eko, Kedudukan dan Kewenangan Desa, Forum Pengembangan Pembaharuan Desa, Yogyakarta: FPPD, 2014.

Thoha, Miftah, Birokrasi Pemerintah Indonesia Di Era Reformasi, Cetakan Ke II, Jakarta: Kencana Prenada Media Group, 2009. 